\title{
THE ANTIMALARIAL FERROQUINE: FROM BENCH TO CLINIC
}

\author{
BIOT C.*, NOSTEN F.**, FRAISSE L.***, TER-MINASSIAN D.****, KHALIFE J.****** \& DIVE D.******
}

\section{Summary:}

Ferroquine (FQ, SSR97193) is currently the most advanced organometallic drug candidate and about to complete phase II clinical trials as a treatment for uncomplicated malaria. This ferrocenecontaining compound is active against both chloroquine-susceptible and chloroquine-resistant Plasmodium falciparum and $P$. vivax strains and/or isolates. This article focuses on the discovery of FQ, its antimalarial activity, the hypothesis of its mode of action, the current absence of resistance in vitro and recent clinical trials.

KEY WORDS: malaria, bioorganometallics, drug candidate, ferroquine, mechanism of action, resistance.

\section{THE MALARIA PROBLEM}

W ith approximately 243 million cases and more than 800,000 deaths reported in 2009 , malaria remains the most important human parasitic disease. Among the five Plasmodium species able to infect human, $P$. falciparum is responsible for most cases of severe disease and death, mainly in African children below the age of five. The morbidity caused by $P$. vivax in tropical countries outside of Africa has long been underestimated (Anstey et al., 2009, Baird, 2009). Malaria is a factor of poverty

\footnotetext{
* Unité de Catalyse et Chimie du Solide, CNRS UMR 8181, Université Lille Nord de France, Université Lille 1, BP 90108, 59652 Villeneuve d'Ascq Cedex, France. Present address: Unité de Glycobiologie Structurale et Fonctionnelle, CNRS UMR 8576, IFR 147, Université Lille Nord de France, Université de Lille 1, 59650 Villeneuve d'Ascq Cedex, France. ** Shoklo Malaria Research Unit, PO Box 46 Mae Sot Tak 63110, Thailand. Faculty of Tropical Medicine, Mahidol University, Bangkok 10400, Thailand. Centre for Clinical Vaccinology and Tropical Medicine, Nuffield Department of Clinical Medicine, University of Oxford, Oxford, United Kingdom.

**: Sanofi-Aventis, Centre de Toulouse, 195, route d'Espagne, BP 13669, 31036 Toulouse, France.

****: Sanofi-Aventis Research and Development, 1, avenue Pierre Brossolette, 91385 Chilly Mazarin Cedex, France.

******: CIIL, Inserm U1019, CNRS UMR 8024, Université Lille Nord de France, Institut Pasteur de Lille, 1, rue du Pr Calmette, 59019 Lille Cedex, France. Correspondence: Christophe Biot.

Tel.: 33 (0)3204369 41.

E-mail: christophe.biot@univ-lille1.fr
}

Résumé : L'ACTIVITÉ ANTIPALUDIOUE DE LA FERROQUINE : DE LA RECHERCHE À LA CLINIQUE

La ferroquine (FQ, SSR97193) est actuellement le candidat médicament organométallique le plus avancé dans son développement industriel et, en tant que traitement du paludisme non compliqué, il devrait bientôt voir s'achever des études cliniques de phase II. Ce composé à base de ferrocène est extrêmement actif contre des isolats et/ou des clones de Plasmodium falciparum et de $P$. vivax sensibles ou résistants à la chloroquine. Cet article présente la découverte de la FQ, son activité antipaludique, les hypothèses liées à son mode d'action, l'absence actuelle de résistance in vitro et, enfin, les récents essais cliniques.

MOTS-CLÉS : paludisme, bio-organométallique, candidat médicament, ferroquine, mécanisme d'action, résistance.

in endemic countries (Stratton et al., 2008). In the absence of an effective vaccine and reliable approaches for vector control, chemotherapy remains the corner stone of malaria control. Quinine has been the first widely used antimalarial drug. Synthetic derivatives of quinine were the 8-aminoquinoline primaquine and the 4-aminoquinoline chloroquine (CQ). When resistance to CQ emerged in the late 1950s, the strategy was to modify the chemical structure of the existing compounds. The synthesis of CQ-like drugs led to the discovery of amodiaquine (AQ) and later mefloquine (MQ), halofantrine in the United States and lumefantrine in China (Baird, 2005). But the pace of new drug development has been slow and no new antimalarial drugs have been introduced into clinical practice since artemether-lumefantrine registered in 1998 (Olliaro \& Wells, 2009). For all new antimalarial drugs introduced the risk of resistance can be reduced by combination therapy (White, 1999; Nosten \& White, 2007). In 2006, the WHO guidelines recommended new treatments combining two drugs with different mechanisms of action. Treatments containing an artemisinin derivative (artemisinin-combination therapies, ACTs) are now standard treatment for falciparum malaria. However, a decline of susceptibility to artesunate has been recently reported in the ThaiCambodian border region (Dondorp et al., 2010). So the search for new molecules with antimalarial activity is more important than ever. 
Many strategies can be used for the search of affordable and efficient antimalarial drugs. These strategies include ethnopharmacology (i.e. bio-evaluation of the efficiency of traditional medicines), medicinal chemistry, combinatorial chemistry and chemical libraries screening by high throughput screening, and drug design. These strategies have led to the discovery of potential antimalarials such as the synthetic endoperoxides and others (Dhanawat et al., 2009). But the clinical development of new compounds is often been stopped for various reasons: toxicity, chemistry, pharmacology, or economics, and less than one in ten promising molecules that have entered the pipeline reaches the stage of clinical studies. In the mid90s, we extended the strategy developed by Gérard Jaouen (Vessieres et al., 1988) in anticancer therapy to antimalarial therapy (see Chavain \& Biot, 2010 for review). The main antimalarials in current use (CQ, quinine, mefloquine, artemisinin, atovaquone) were modified by introduction of a ferrocenyl moiety in their chemical structure. More than 150 ferrocenic analogues have been synthesized, by us and others (Biot \& Dive, 2010). The ferrocenic analogues were systematically tested against in vitro cultures of $P$. falciparum with CQ-susceptible and CQ-resistant strains. Ferroquine (FQ, SSR97193) was rapidly identified as a lead compound to meet candidate nomination requirements (Biot et al., 1997). The clinical phase IIb study (efficacy/safety in adults, adolescents and children) began in 2009 in Africa.

This mini-review will focus on the discovery of $F Q$, its antimalarial activity, the hypothesis of its modes of action and recent clinical trials.

\section{THE ORGANOMETALLIC ANTIMALARIAL COMPOUND SET}

ince 1993, we and others have systematically prepared organometallic versions of the anti$\bigcup$ malarials in current use such as CQ, primaquine, mepacrine, mefloquine, quinine, artemisinin, and atovaquone (see Dive \& Biot, 2008 for review). New sandwiches and half-sandwiches metal complexes (Dunitz et al., 1956) have been synthesized and characterized. In vitro tests of their antimalarial activity were performed. Other organometallic compounds with a priori unknown antimalarial activity were still screened. A collection of almost 150 compounds was made available. Among the organometallicdrug hybrids, the most interesting compounds were the ferrocene-drug hybrids and among those the ferrocene-chloroquine hybrids were the most promissing (Fig. 1).
Note here that the ferrocene-artemisitene hybrids showed also interesting properties with activities equal to artemisinin (Delhaes et al., 2000, Dive \& Biot, 2008). In the ferrocene-CQ hybrids series, we have shown that the ferrocene moiety has to be covalently flanked by a 4-aminoquinoline and an alkylamine (Biot et al., 2006). Ferroquine (FQ, SSR97193) was the first compound synthesized by us (Biot et al., 1997). Later, a second generation of analogues of FQ was designed and investigated. For example, we synthesized dual molecules including a FQ analogue conjugated with a glutathione reductase inhibitor or a glutathione depletory (Chavain et al., 2009) Nevertheless, this strategy failed to identify a "new" lead for a further development. More interestingly, amino-alcohols based on the FQ structure are active against CQ-susceptible $\left(\mathrm{CQ}^{\mathrm{S}}\right)$ and $\mathrm{CQ}$-resistant $\left(\mathrm{CQ}^{\mathrm{R}}\right)$ clones of $P$. falciparum. In addition, in this second generation of analogues the ferrocenic amino-alcohols exert antiviral effects with some selectivity toward SARS-CoV infection (Biot et al., 2006b).

\section{ANTIMALARIAL ACTIVITY OF FERROQUINE}

\section{ANTIMALARIAL ACTIVITY ON LABORATORY CLONES}

$\triangle \mathrm{in}$ Q antimalarial activity was compared to that of CQ with standard in vitro parasite growth inhibition method, based on tritiated hypoxanthin incorporation in erythrocytes infected with $P$. falciparum, incubated 48 hours (Desjardins et al., 1978). Preliminary studies have shown that FQ was equally active as a base, ditartrate or dichlorhydrate salts (unpublished results).

Tests results available from 11 studies performed in different laboratories and using $19 \mathrm{CQ}^{\mathrm{S}}$ and $\mathrm{CQ}^{\mathrm{R}} P$. falciparum laboratory adapted clones are represented in Fig. 2. The results show that the response to CQ can be easily dissociated between susceptible and resistant clones, which are spread respectively on either sides of the $100 \mathrm{nM} \mathrm{IC}_{50}$ for CQ. However, FQ is equally active on both types of clone and is at least equally active and often more active than CQ on $\mathrm{CQ}^{\mathrm{S}}$ parasites. No resistance to $\mathrm{FQ}$ occurred in $\mathrm{CQ}^{\mathrm{R}}$ clones and no correlation was found between susceptibility to FQ and polymorphism in transport proteins implicated in quinoline resistance (Henry et al., 2008).

\section{IN VIVO ANTIMALARIAL ACTIVITY IN RODENT MODELS}

Antimalarial activity of $\mathrm{FQ}$ was tested on various rodent malaria strains (P. berghei, P. yoelii, P. vinckei) by the standard four day test of Peters (1987) adapted 


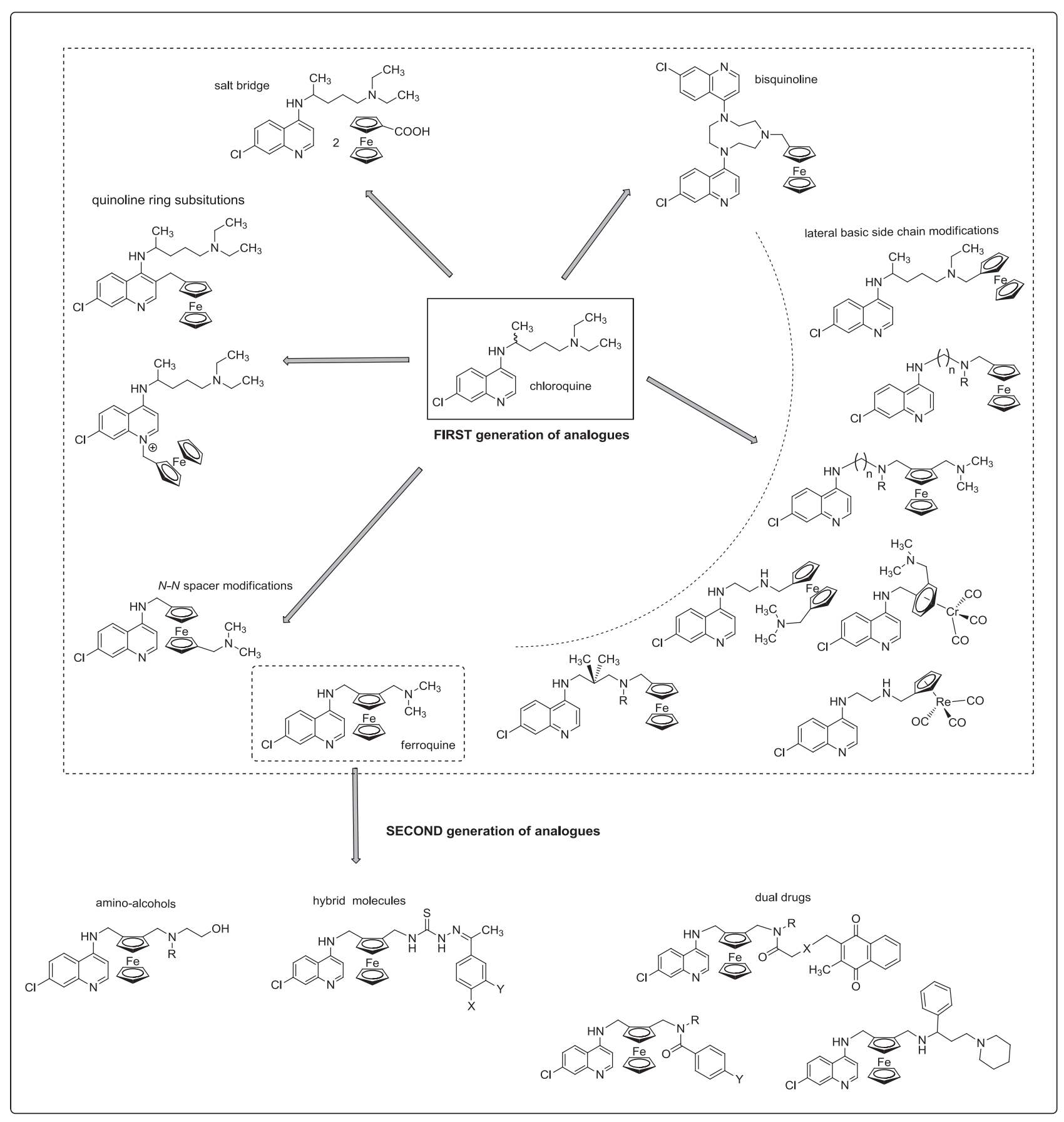




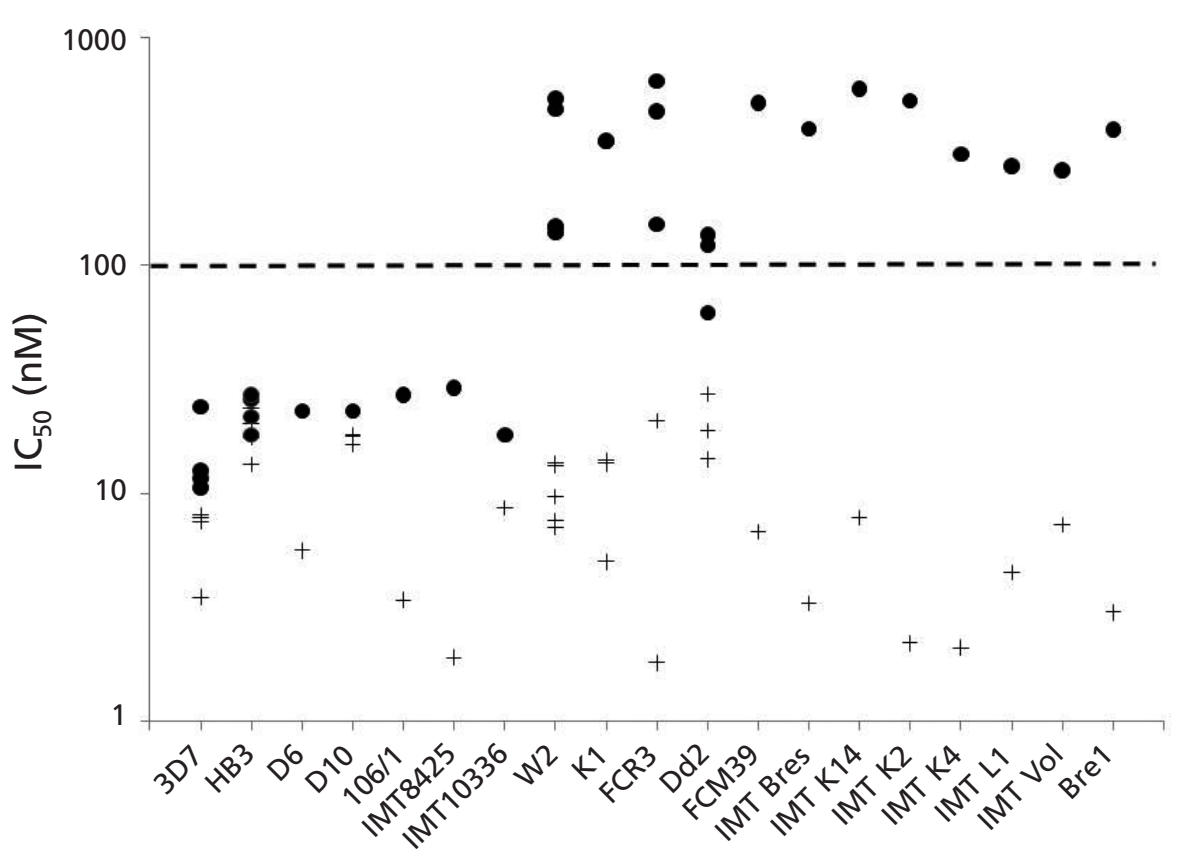

Fig 2. - Susceptibility of 19 laboratory $P$. falciparum clones to $\mathrm{CQ}$ and $\mathrm{FQ}$ compiled from 11 different published studies.

$\mathrm{IC}_{50}$ for CQ for each clone tested $(\bullet)$. $+\mathrm{IC}_{50}$ for $\mathrm{FQ}$ for each clone tested $(+)$. The doted line indicate the threshold of resistance to CQ (Le Bras \& Ringwald, 1990).

References associated to each clone tested: 3D7 (1, 6, 8, 9, 10); HB3 (1, 7, 9, 10); D10 (2, 3, 4, 5); W2 (1, 6, 8, 9, 10); K1 (2, 3, 4, 5); FCR3 (1, 6, 11); Dd2 (7, 10, 11); D6, 106/1, IMT8425, IMT10336, FCM39, IMT Bres, IMT K14, IMT K2, IMT K4, IMT L1, IMT Vol, Bre1 (1).

References: 1: Henry et al., 2008; 2 : Beagley et al., 2002; 3: Beagley et al., 2003, 4: Blackie et al., 2007; 5: Blackie \& Chibale 2008; 6 Biot et al., 2006b; 7: Biot et al., 1999; 8: Biot et al., 2006a; 9: Daher et al., 2006a; 10: Daher et al., 2006b; 11: Delhaes et al., 2001.

\section{ENANTIOMERS}

As FQ is a racemic compound. The two stereoisomers were synthetized and showed an antimalarial activity similar to that of the parent compound in vitro (Delhaes et al., 2002).

\section{MetabolizATION AND ACTIVITY OF METABOlites}

It was first postulated that the metabolism of $\mathrm{FQ}$ may share a common pathway with that of CQ and potential metabolites ( $N$-monodemethyl-FQ and $N$ didemethyl-FQ) were synthesized and tested (Biot et al., 1999). The metabolism of FQ was then studied in details in vitro and enabled to determine its degradation pathway (Daher et al., 2006a). In vitro FQ is mainly metabolized to a major $N$-monodemethylated metabolite, SSR97213 (EVT0233) and to a further potential metabolite that is an $N$-didemethylated compound. Antimalarial activity of $\mathrm{N}$-monodemethyl-FQ was found to be comparable to that of parent compounds on two $\mathrm{CQ}^{\mathrm{S}}$ clones and remained much more active than CQ on two $\mathrm{CQ}^{\mathrm{R}}$ clones. On the another hand, $N$-didemethyl-FQ had a decreased activity on $\mathrm{CQ}^{\mathrm{R}}$ clones, mainly if $\mathrm{IC}_{90}$ of compounds is taken into account (Daher et al., 2006a).

\section{EFFICACY ON CLINICAL ISOLATES}

Compounds were evaluated with standard in vitro parasite growth inhibition methods, in erythrocytes infected with $P$. falciparum, incubated at least 24 hours with the drugs. The antimalarial activity of FQ (SSR97193) on blood clinical isolates $\left(\mathrm{CQ}^{\mathrm{S}}, \mathrm{CQ}^{\mathrm{R}}\right.$, and multi-drug resistant isolates) infected by P. falciparum was assessed in seven different studies of African patients (Senegal, Gabon) (Pradines et al., 2001 \& 2002; Atteke et al., 2003; Kreidenweiss et al., 2006), or southeast Asian patients (Chim et al., 2004; Barends et al., 2007) in comparison with existing antimalarial drugs. Data on FQ, CQ, and artesunate are reported in Table I.

Taking all these studies together, FQ was evaluated on 534 clinical isolates, 220 from Southeast Asia and 314 from Africa. In all these studies, FQ, like artesunate, displayed a very potent antimalarial activity against $P$. falciparum (range $\mathrm{IC}_{50}$ below $30 \mathrm{nM}[13 \mathrm{ng} / \mathrm{mL}]$ for FQ and below $4 \mathrm{nM}[1.5 \mathrm{ng} / \mathrm{mL}]$ for artesunate) with equal efficacy upon $\mathrm{CQ}^{\mathrm{S}}$ and $\mathrm{CQ}^{\mathrm{R}}$ clinical isolates (resistant isolates, with $\mathrm{IC}_{50}$ over $100 \mathrm{nM}$, represented from $32 \%$ to $100 \%$ of samples).

In addition, in the study from Thailand the main FQ in vivo metabolite (SSR97213) was investigated (Barends et al., 2007). SSR97213 was shown to be highly potent against $P$. falciparum $\left(\mathrm{N}=64, \mathrm{IC}_{50}=37 \mathrm{nM}\right.$ with $95 \%$ confidence intervals [CIs] $=34.3$ to $39.9 \mathrm{nM}$, or $\mathrm{IC}_{50}=$ $16.0 \mathrm{ng} / \mathrm{mL}$ with $95 \% \mathrm{CIs}=14.9$ to $17.3 \mathrm{ng} / \mathrm{mL}$ ) on all the clinical isolates. To investigate whether $P$. vivax was sensitive to FQ a study was conducted in northwestern Thailand on 63 isolates collected from October 2006 to April 2009 to examine the effects of FQ and its demethylated metabolite (SSR97213) on the ring stage and the schizont maturation by microscopy. All samples were collected from patients with acute P. vivax who had mono-species parasitaemia of $>100 / 500$ white blood cells. FQ was found to have a potent $e x$ 


\begin{tabular}{|c|c|c|c|c|c|c|c|c|c|c|c|}
\hline \multirow[b]{2}{*}{ Country } & \multicolumn{3}{|c|}{ Ferroquine } & \multicolumn{4}{|c|}{ Chloroquine } & \multicolumn{3}{|c|}{ Artesunate } & \multirow[b]{2}{*}{ Reference } \\
\hline & $\mathbf{n}$ & $\begin{array}{c}\mathrm{IC}_{50}(\mathrm{nM}) \\
(\mathrm{ng} / \mathrm{mL})\end{array}$ & $\begin{array}{c}95 \% \\
\text { CI }\end{array}$ & $\mathbf{n}$ & $\begin{array}{c}\mathrm{IC}_{50}(\mathrm{nM}) \\
(\mathrm{ng} / \mathrm{mL})\end{array}$ & $\begin{array}{l}95 \% \\
\text { CI }\end{array}$ & $\begin{array}{c}\% \\
\text { resistance }\end{array}$ & $\mathbf{n}$ & $\begin{array}{c}\mathrm{IC}_{50}(\mathrm{nM}) \\
(\mathrm{ng} / \mathrm{mL})\end{array}$ & $\begin{array}{c}95 \% \\
\text { CI }\end{array}$ & \\
\hline Gabon & 103 & $\begin{array}{r}10.8 \\
4.7\end{array}$ & $\begin{array}{c}8.6-13.5 \\
3.8-5.9\end{array}$ & 102 & $\begin{array}{l}370 \\
118.4\end{array}$ & $\begin{array}{l}319-429 \\
102-137\end{array}$ & 95 (a) & 65 & $\begin{array}{l}2.9 \\
1.1\end{array}$ & $\begin{array}{l}2.3-3.7 \\
0.9-1.4\end{array}$ & $\begin{array}{l}\text { Biot et al. } \\
\quad 1999\end{array}$ \\
\hline Senegal & 55 & $\begin{array}{l}7.9 \\
3.4\end{array}$ & $\begin{array}{l}6.5-9.7 \\
2.8-4.2\end{array}$ & 53 & $\begin{array}{l}102 \\
32.6\end{array}$ & $\begin{array}{c}74-140 \\
23.7-44.8\end{array}$ & 55 (a) & 51 & $\begin{array}{l}1.9 \\
0.7\end{array}$ & $\begin{array}{l}1.5-2.3 \\
0.6-0.9\end{array}$ & $\begin{array}{l}\text { Biot et al. } \\
2006 a\end{array}$ \\
\hline Gabon & 56 & $\begin{array}{l}16 \\
6.9\end{array}$ & $\begin{array}{c}14.4-17.8 \\
6.3-7.8\end{array}$ & 56 & $\begin{array}{l}141 \\
45.1\end{array}$ & $\begin{array}{c}70-285 \\
22.4-91.2\end{array}$ & 52 (a) & $\mathrm{nt}$ & nt & $\mathrm{nt}$ & $\begin{array}{c}\text { Daher et al. } \\
\text { 2006a }\end{array}$ \\
\hline Gabon & 60 & $\begin{array}{l}27.9 \\
12.1\end{array}$ & $\begin{array}{l}2.3-33.2 \\
1.0-14.5\end{array}$ & 60 & $\begin{array}{l}398 \\
127.3\end{array}$ & $\begin{array}{l}166-956 \\
53.1-306\end{array}$ & 97 (a) & $\mathrm{nt}$ & nt & $\mathrm{nt}$ & $\begin{array}{c}\text { Daher et al., } \\
2006 \mathrm{a}\end{array}$ \\
\hline Thailand & 65 & $\begin{array}{l}9.3 \\
4.0\end{array}$ & $\begin{array}{l}8.7-10.0 \\
3.8-4.4\end{array}$ & 62 & $\begin{array}{l}341 \\
109.1\end{array}$ & $\begin{array}{c}304-382 \\
87.2-122\end{array}$ & 100 (a) & 56 & $\begin{array}{l}4.0 \\
1.5\end{array}$ & $\begin{array}{l}3.1-6.3 \\
1.2-2.4\end{array}$ & $\begin{array}{c}\text { Daher et al., } \\
\text { 2006b }\end{array}$ \\
\hline Gabon & 40 & $\begin{array}{l}1.9 \\
0.8\end{array}$ & $\begin{array}{l}0.6-6.7 \\
0.3-3.0\end{array}$ & 43 & $\begin{array}{l}113 \\
36.1\end{array}$ & $\begin{array}{c}12.4-332 \\
4.0-106\end{array}$ & 100 (b) & 43 & $\begin{array}{l}1.0 \\
0.4\end{array}$ & $\begin{array}{l}0.2-6.0 \\
0.1-2.3\end{array}$ & $\begin{array}{c}\text { Delhaes et al., } \\
2001\end{array}$ \\
\hline Cambodia & 155 & $\begin{array}{l}29 \\
12.6\end{array}$ & $\begin{array}{l}26.3-31.6 \\
11.6-13.8\end{array}$ & 155 & $\begin{array}{l}135 \\
43.1\end{array}$ & $\begin{array}{c}121-151 \\
38.7-48.2\end{array}$ & 32 (a) & 150 & $\begin{array}{l}1.1 \\
0.4\end{array}$ & $\begin{array}{l}1.0-1.2 \\
0.4-0.5\end{array}$ & EVT0231 \\
\hline
\end{tabular}

$\mathrm{n}=$ number of clinical sites; $\mathrm{nt}=$ not tested; $\mathrm{CI}=$ confidence interval; $\mathrm{IC}_{50}=$ inhibitory concentration decreasing a response by $50 \%$; (a) $=\%$ of resistance using the threshold level of resistance $\mathrm{IC}_{50}>100 \mathrm{nM}$; (b) $=\%$ of resistance using the threshold of $\mathrm{IC}_{99}>30 \mathrm{nM}$ for the HRP2 detection assay. For values in italics, units $=\mathrm{ng} / \mathrm{mL}$, calculated for translation to a free-base or free-acid gravimetric concentration.

Table I. - Effect of FQ (SSR97193 - $\mathrm{IC}_{50}$ and $95 \%$ confidence intervals) on P. falciparum clinical isolates from different studies.

vivo effect on $P$. vivax schizont maturation (median $\mathrm{IC}_{50}=15 \mathrm{nM} ; 75 \%$ CIs $=12$ to $\left.20 \mathrm{nM}, \mathrm{n}=52\right)$ with SSR97213 being less active $\left(\mathrm{IC}_{50}=77 \mathrm{nM} ; 75 \%\right.$ CIs $=$ 14 to $205 \mathrm{nM}$ ), and no significant cross-sensitivity between FQ and other antimalarials was detected; consequently FQ may be a suitable replacement for chloroquine in the treatment of drug-resistant $P$. vivax malaria (Leimanis et al., 2010). In the Gabonese study (Kreidenweiss et al., 2006), $\mathrm{IC}_{99}$ s were reported in comparison with $\mathrm{IC}_{50} \mathrm{~s}$ (Kreidenweiss et al., 2006). For artesunate and $\mathrm{FQ}$, the $\mathrm{IC}_{99} \mathrm{~s}$ were $5.76 \mathrm{nM}(95 \% \mathrm{CIs}=$ 0.57 to $49.1 \mathrm{nM})$ or $\mathrm{IC}_{50}=2.21 \mathrm{ng} / \mathrm{mL}(95 \%$ CIs $=$ 0.22 to $18.9 \mathrm{ng} / \mathrm{mL})$, and $5.75 \mathrm{nM}(95 \%$ CIs $=1.10$ to $56.9 \mathrm{nM})$ or $\mathrm{IC}_{50}=2.50 \mathrm{ng} / \mathrm{mL}(95 \%$ CIs $=0.48$ to $24.8 \mathrm{ng} / \mathrm{mL}$ ). These values are close to the reported $\mathrm{IC}_{50} \mathrm{~s}$, indicating a strong potency and the ability to efficiently kill all parasites present in the field isolates.

Finally, the susceptibility of $P$. falciparum isolates from Madagascar $(n=21)$, Guyana $(n=65)$ and Cambodia $(n=62)$ to FQ was measured at the local Pasteur Institutes using the $\left[{ }^{3} \mathrm{H}\right]$-hypoxanthine incorporation method. The mean $\mathrm{IC}_{50}$ (with minimum and maximum $\mathrm{IC}_{50}$ values), were $5.96 \mathrm{nM}(0.2-43.2), 8.68 \mathrm{nM}$ (3.0555.77) and $10.18 \mathrm{nM}(2.53-43.43)$, respectively (Eric Legrand, personal communication).

In all studies, no cross-resistance was observed with CQ and other antimalarials, although weak occurrences could be attributed, in one study to fluctuations of initial inoculums used for test (Kreidenweiss et al., 2006). This absence of cross-resistance is supported by molecular studies, which showed that there was no association between polymorphims of resistance of $p f c r t$ gene, the main molecular marker for CQ, and FQ susceptibility in field isolates (Daher et al., 2006b). This last observation was then extended to other markers of quinoline resistance (Henry et al., 2008) and to pymdr and pycrt genes of the rodent strain P. yoelii (Dive \& Biot, 2008).

\section{RESISTANCE ACQUISITION UNDER FERROQUINE PRESSURE}

An in vitro study on P. falciparum resistance acquisition under ferroquine pressure was performed on human red blood cells infected with the W2 clone. After two months of FQ pressure we were unable to obtain a viable resistant strain. During these experiments however, we observed very few parasites, which were unable to develop when transferred in drug-free medium (Daher et al., 2006b).

An attempt to obtain a rodent $\mathrm{FQ}^{\mathrm{R}}$ strain starting from $P$. yoelii resulted in a phenotype that was not fixed genetically the resistance disappearing as soon as FQ pressure was removed. Moreover, the phenotype was emerging very slowly and was confined strictly to reticulocytes and easily cleared by the host (Dive \& Biot, 2008).

These results clearly show that the fitness cost of FQ resistance is very high for the parasite and that it would be detrimental for them in competition with non-resistant clones. 


\begin{tabular}{|c|c|c|}
\hline Properties & CQ & $\mathbf{F Q}$ \\
\hline Intramolecular hydrogen bond & Yes & Yes \\
\hline $\begin{array}{l}\text { Weak base properties }\left(\mathrm{p} K_{\mathrm{a} 1} \text { and } \mathrm{p} K_{\mathrm{a} 2}\right. \\
\text { values) }\end{array}$ & $\begin{array}{l}10.03 \\
\text { and } 7.94\end{array}$ & $\begin{array}{c}8.19 \\
\text { and } 6.99\end{array}$ \\
\hline $\begin{array}{l}\text { Neutral and protonated forms at vacuolar } \\
\mathrm{pH}\end{array}$ & One time & Ten times \\
\hline Lipophilicity at $\mathrm{pH} 5.2$ & -1.2 & -0.77 \\
\hline Lipophilicity at $\mathrm{pH} 7.4$ & 0.85 & 2.95 \\
\hline Complex with hematin and stoichiometry & Yes $(1: 1)$ & Yes $(1: 1)$ \\
\hline $\begin{array}{l}\text { Interaction with monomeric hematin } \\
(\log \mathrm{K})\end{array}$ & Yes (5.52) & Yes (5.52) \\
\hline Inhibition of $\beta$-hematin formation (IRS) & Yes & Yes \\
\hline BHIA $_{50}$ & 1.9 & 0.78 \\
\hline Production of hydroxyl radicals & No & Yes \\
\hline Activity on $\mathrm{CQ}^{\mathrm{R}}$ clones and isolates & No & Yes \\
\hline $\begin{array}{l}\text { Relation with specific molecular } \\
\text { resistance markers }\end{array}$ & Yes & No \\
\hline
\end{tabular}

IRS $=$ infrared spectroscopy. BHIA $_{50}=50 \%$ inhibitory concentration for $\beta$-hematin inhibition in equivalents of compounds to hemin (Biot et al., 2005).

Table II. - Comparative properties of chloroquine (CQ) and ferroquine $(\mathrm{FQ})$.

\section{MODES OF ACTION: HYPOTHESES}

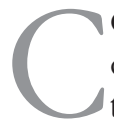

$Q$ is thought to act by interfering with the digestion of haemoglobin in the blood stages of the malaria life cycle. Even if CQ and FQ share some similarities in their activity, FQ clearly showed important and additional mechanisms of action when compared to CQ (Table II) (Biot et al., 2005; Dubar et al., 2011).

The weaker base properties of FQ compared to CQ combined with its higher lipophilicity at $\mathrm{pH} 7.4$ and the peculiar conformation provided by the intra-molecular hydrogen bond present in non polar conditions result in a better potency for FQ to cross membranes and a higher accumulation in the digestive vacuole. At the $\mathrm{pH}$ in that organelle, the physicochemical properties of FQ evidenced a higher fraction of neutral and mono-protonated forms and suggested a more efficient inhibitory activity on hematin biocrystallization (Dubar et al., 2011), which was verified in vitro in BHIA ( $\beta$-Hematin Inhibition Assay). Moreover, preferential localization of FQ at the site of crystallization of hemozoin close to the membrane of acidic vacuole might induce two independent or concomitant behaviours: first FQ might inhibit the self assembly of the hemozoin crystal and second FQ might specifically generate reactive oxygen species (per se, or via destruction of the hemozoin crystal) and induce lipid peroxidation and alteration of digestive vacuole (Chavain et al., 2008; Dubar et al., 2011).

All these properties might explain why FQ is more active than CQ in vitro even in a susceptible $P$. falciparum clone. The in vitro assays emphasized the specific importance of the intra-molecular hydrogen bond in FQ. Indeed in our studies based on methylFQ (an analogue of FQ without the intra-molecular hydrogen bond due to the presence of a methyl group on the 4-amino group), we clearly showed that the presence of the intra-molecular hydrogen bond allows FQ to escape resistance mechanisms and avoid crossresistance with the current antimalarials (Biot et al., 2009; Dubar et al., 2011).

\section{CLINICAL TRIALS}

A total of 335 subjects, or patients have been administered with FQ (SSR97193) as of June 28 2010. In seven completed Phase 1/2 studies, 173 males subjects/patients were part of two trials performed in healthy Caucasian subjects, four trials conducted in asymptomatic African patients infected with $P$. falciparum, and one Phase IIa dose-escalation safety and activity (including adult African patients with mono-infection with $P$. falciparum and parasitemia within the 100 to 200,000/ $\mathrm{L}$ limits). Ongoing phase IIb dose-range study accounting for 440 patients conducted across seven African countries is currently assessing in four groups the safety and efficacy of an association of FQ-at a three dose level- with artesunate and FQ alone in patients with mono infection with P. falciparum. The first and second cohort consisting of adult/adolescent patients and children $>20 \mathrm{~kg}$ has been completed. Other potential combinations and indications are under evaluation at the time of writing this review.

\section{CONCLUSIONS AND PERSPECTIVES}

T $\mathrm{n}$ conclusion, FQ clinical trials will enable the definition of conditions of use of this new antimalarial drug, which appears to be well positioned in the pipeline. One remaining question is the cause of the potent activity of the drug, mainly towards CQ resistant parasites, and its relation with the structure of the molecule. Some clues (role of the hydrogen bond, role of redox activity, nature of the metal present in the metallocene moiety) are currently under examination to clarify the mechanisms of entry of FQ in the infected red blood cell, its site and mechanism of action and its relation with the transporters involved in resistance against different aminoquinolines, which appear ineffective to expel the molecule out of the 
parasite. On the clinical front, it remains to determine how this new drug will be best combined with a partner to limit the risk of resistance.

\section{ACKNOWLEDGEMENTS}

A 11 searches on FQ carried out in laboratories * and ${ }^{* * * * *}$ were funded by Pierre Fabre Médicament and Sanofi-Aventis. The two labs are very grateful to all Ph.D. students who participated to this work (L. Delhaës, H. Abessolo, W. Daher, N. Chavain, and F. Dubar) and provided an excellent work. We acknowledge scientists who collaborated in the research: B. Pradines, T. Egan, K. Chibale, C. Slomianny, X. Trivelli, S. Bohic, E. Curis, and I. Forfar. F. Nosten is supported by the Wellcome Trust of Great Britain. We thank Ministère de l'Enseignement Supérieur, Université Lille Nord de France, CNRS and INSERM.

\section{REFERENCES}

Anstey N.M., Russell B., Yeo T.W. \& Price R.N. The pathophysiology of vivax malaria. Trends Parasitol, 2009, 25, 220-227.

atteke C., Ndong J.M., Aubouy A., Maciejewski L., Brocard J., Lebibi J. \& Deloron P. In vitro susceptibility to a new antimalarial organometallic analogue, ferroquine, of Plasmodium falciparum isolates from the Haut-Ogooue region of Gabon. I Antimicrob Chemother, 2003, 51, 1021-1024.

BAIRD J.K. Effectiveness of antimalarial drugs. $N$ Engl J Med, $2005,352,1565-1577$.

BAIRD J.K. Resistance to therapies for infection by Plasmodium vivax. Clin Microbiol Rev, 2009, 22, 508-534.

Barends M., Jaidee A., KhaOhirun N., Singhasivanon P. \& NosTEN F. In vitro activity of ferroquine (SSR97193) against Plasmodium falciparum isolates from the Thai-Burmese border. Malaria J, 2007, 6, 81.

Beagley P., Blackie M.A.L., Chibale K., Clarkson C., Moss J.R. \& SмIтH P.J. Synthesis and antimalarial activity in vitro of new ruthenocene-chloroquine analogues Dalton Trans, 2002, 2002, 4426-4433.

Beagley P., Blackie M.A.L., Chibale K., Clarkson C., Meijboom R., Moss J.R., Smith P.J. \& Su H. Synthesis and antiplasmodial activity in vitro of new ferrocene-chloroquine analogues. Dalton Trans, 2003, 2003, 3046-3051.

Biot C., Glorian G., Maciejewsini L.A., Brocard J.S., Millet P., Georges A.J., Abessolo H., Dive D. \& Lebibi J. Synthesis and antimalarial activity in vitro and in vivo of a new ferrocene-chloroquine analogue. J Med Chem, 1997, 40, 3715-3718.

Biot C., Delhaës L., N’Diaye C.M., Maciejewski L.A., Camus D., Dive D. \& BROCARD J.S. Synthesis and antimalarial activity in vitro of potential metabolites of ferrochloroquine and related compounds. Bioorg Med Chem, 1999, 7, 2843-2847.
Biot C., Taramelli D., Forfar-Bares I., Maciejewski L.A., Boyce M., Nowogrocki G., Brocard J.S., Basilico N., Olliaro P. \& Egan T.J. Insights into the mechanism of action of ferroquine. Relationship between physicochemical properties and antiplasmodial activity. Mol Pharm, 2005, 2, 185-193.

Biot C., Daher W., Jarry C., Ndiaye C.H., Pelinski L., Khalife J., Fraisse L., Brocard J., Melnyk P., Forfar-Bares I. \& Dive D. Probing the role of the covalent linkage of ferrocene into a chloroquine template. J Med Chem, 2006a, 49, 4707-4714.

Biot C., Daher W., Chavain N., Fandeur T., Khalife J., Dive D. \& De Clerce E. Design and synthesis of hydroxyferroquine derivatives with antimalarial and antiviral activities. $J$ Med Chem, 2006b, 49, 2845-2849

Biot C., Pradines B., Sergeant M.H., Gut J., Rosenthal P.J. \& Chibale K. Design, synthesis, and antimalarial activity of structural chimeras of thiosemicarbazone and ferroquine analogues. Bioorg Med Chem Lett, 2007, 17, 6434-6438.

Biot C., Chavain N., Dubar F., Pradines B., Brocard J., Forfar I. \& Dive D. Structure-activity relationships of $4-\mathrm{N}$-substituted ferroquine analogues. Time to re-evaluate the mechanism of action of ferroquine. J Organomet Chem, 2009, 694, 845-854.

Biot C. \& Dive D. Bioorganometallic chemistry and malaria. Top Organomet Chem, 2010, 32, 155-193.

Blackie M.A., Beagley P., Croft S.L., Kendrick H., Moss J.R. \& Chibale K. Metallocene-based antimalarials: an exploration into the influence of the ferrocenyl moiety on in vitro antimalarial activity in chloroquine-sensitive and chloroquine-resistant strains of Plasmodium falciparum. Bioorg Med Chem, 2007, 15, 6510-6516.

Blackie M.A. \& Chibale K. Metallocene antimalarials: the continuing quest. Met Based Drugs, 2008, 2008, 495123.

Chavain N., Vezin H., Dive D., Touati N., Paul J.F., Buisine E. \& Biот C. Investigation of the redox behavior of ferroquine, a new antimalarial. Mol Pharm, 2008, 5, 710-716.

Chavain N., Davioud-Charvet E., Trivelli X., Mbeki L., RotTMANN M., BRUn R. \& Biot C. Antimalarial activities of ferroquine conjugates with either glutathione reductase inhibitors or glutathione depletors via a hydrolyzable amide linker. Bioorg Med Chem, 2009, 17, 8048-8059.

Chavain N. \& Biot C. Organometallic complexes: new tools for chemotherapy. Curr Med Chem, 2010, 17, 2729-2745.

Chim P., Lim P., Sem R., Nhem S., Maciejewsin L. \& Fandeur T. The in-vitro antimalarial activity of ferrochloroquine, measured against Cambodian isolates of Plasmodium falciparum. Ann Trop Med Parasitol, 2004, 98, 419-424.

Daher W.E., Pelinski L., Klieber S., Sadoun F., Meunier V., Bourrie M., Biot C., Guillou F., Fabre G., Brocard J., Fraisse L., Maffrand J.P., Khalife J. \& Dive D. In vitro metabolism of ferroquine (SSR97193) in animal and human hepatic models and antimalarial activity of major metabolites on Plasmodium falciparum. Drug Metab Dispos, 2006a, 34, 667-682.

Daher W., Biot C., Fandeur T., Jouin H., Pelinski L., Viscogliosi E., Fraisse L., Pradines B., Brocard J., Khalife J. \& Dive D. Assessment of $P$. falciparum resistance to ferro- 
quine in field isolates and in W2 strain under pressure. Malaria J, 2006b, 5, 11.

Delhaës L., Biot C., Berry L., Maciejewski L.A., Camus D., Brocard J.S. \& Dive D. Novel ferrocenic artemisinin derivatives: synthesis, in vitro antimalarial activity and affinity of binding with ferroprotoporphyrin IX. Bioorg Med Chem, 2000, 8, 2739-2745.

Delhaës L., Abessolo H., Biot C., Deloron P., Karbwang J., Mortuaire M., Maciejewski L.A., Camus D., Brocard J. \& Dive D. Ferrochloroquine, a ferrocenyl analogue of chloroquine, retains a potent activity against resistant Plasmodium falciparum in vitro and P. vinckei in vivo. Parasitol Res, 2001, 87, 239-244.

Delhaës L., Biot C., Berry L., Delcourt P., Maciejewsiki L.A., Camus D., Brocard J.S. \& Dive D. Synthesis of ferroquine enantiomers. First investigation of metallocenic, chirality upon antimalarial activity and cytotoxicity. ChemBioChem, 2002, 3, 101-106.

Desjardin R.E., Canfield C., Haynes J., \& Chulay J. Quantitative assessment of antimalarial activity in vitro by a semiautomated microdilution technique. Antimicrob Agents Chemother, 1979, 16, 710-718.

Dhanawat M., Das N., Nagarwal R.C. \& Shrivastava S.K. Antimalarial drug development: past to present scenario. Mini Rev Med Chem, 2009, 9, 1447-1469.

Dive D. \& Bıот C. Ferrocene conjugates of chloroquine and other antimalarials: the development of ferroquine, a new antimalarial. ChemMedChem, 2008, 3, 383-391.

Dondorp A.M., Yeung S., White L., Nguon C., Day N.P., Socheat D. \& VON SEIDLEIN L. Artemisinin resistance: current status and scenarios for containment. Nat Rev Microbiol, 2010, 8, 272-280.

Dubar F., Egan T.J., Pradines B., Kuter D., Ncokazi K.K., Forge D., Paul J.P., Pierrot C., Kalamou H., Khalife J., Buisine E., Rogier C., Vezin H., Forfar I., Slomianny C., Trivelli X., KapishnikoV S., Leiserowitz L., Dive D. \& Biot C. The antimalarial ferroquine: role of the metal and intramolecular hydrogen bond in activity and resistance. ACS Chem Biol, 2011, 6 (3), 275-287.

Dunitz J., ORgel L. \& Rich A. The crystal structure of ferrocene. Acta Cryst, 1956, 9, 373-375.

Henry M., Briolant S., Fontaine A., Mosnier J., Baret E., Amalvict R., Fusaï T., Fraisse L., Rogier C. \& Pradines B. In vitro activity of ferroquine is independent of polymorphisms in transport protein genes implicated in quinoline resistance in Plasmodium falciparum. Antimicrob Agents Chemother, 2008, 52, 2755-2759.

Kreidenweiss A., Kremsner P.G., Dietz K. \& Mordmueller B. In vitro activity of ferroquine (SSR97193) is independent of chloroquine resistance in Plasmodium falciparum. Amer J Trop Med Hyg, 2006, 75, 1178-1181.

Leimanis M.L., Jaidee A., Sriprawat K., Kaewpongsri S., SuWanarusk R., Barends M., Phyo A.P., Russell B., Renia L. \& Nosten F. Plasmodium vivax susceptibility to ferroquine. Antimicrob Agents Chemother, 2010, 54, 2228-2230.

Nosten F. \& White N.J. Artemisinin-based combination treatment of falciparum malaria. Am J Trop Med Hyg, 2007, 77, 181-192.
Olliaro P. \& Wells T.N. The global portfolio of new antimalarial medicines under development. Clin Pharmacol Ther, 2009, 85, 584-595.

PETERS W. In: Chemotherapy, and drug resistance in malaria. Peters W. (ed.), LiverpoolSchool of Tropical Medicine, Liverpool, 1987, Vol. 1, 145-273.

Pradines B., Fusaï T., Daries W., Laloge V., Rogier C., Millet P., Panconi E., Kombila M. \& Parzy D. Ferrocene-chloroquine analogues as antimalarial agents: in vitro activity of ferrochloroquine against 103 Gabonese isolates of Plasmodium falciparum. J Antimicrob Chemother, 2001, 48, 179-184.

Pradines B., Tall A., Rogier C., Spiegel A., Mosnier J., Marrama L., Fusï T., Millet P., Panconi E., Trape J.F. \& Parzy D. In vitro activities of ferrochloroquine against 55 Senegalese isolates of Plasmodium falciparum in comparison with those of standard antimalarial drugs. Trop Med Int Health, 2002, 7, 265-270.

Stratton L., O’neill M.S., Kruk M.E. \& Bell M.L. The persistent problem of malaria: addressing the fundamental causes of a global killer. Social Sci Med, 2008, 67, 854862.

Vessieres A., Jaouen G., Gruselle M., Rossignol J.L., Savignac M., Top S. \& GREenfield S. Synthesis and receptor binding of polynuclear organometallic estradiol derivatives. I Steroid Biochem, 1988, 30, 301-316.

White N.J. Antimalarial drug resistance and combination therapy. Philos Trans R Soc London B Biol Sci, 1999, 354, 739-749.

Received on January $10^{\text {th }}, 2011$ Accepted on March $28^{\text {th }}, 2011$ 